\title{
原著 IV
}

\section{抗ヒトへモグロビン抗体を用いた 免疫学的便潜血反応の検討}

\begin{tabular}{|c|c|c|c|c|c|c|c|c|c|c|}
\hline \multirow[b]{2}{*}{ 竹 } & \multicolumn{10}{|c|}{ 東京医科大学第 4 内科 } \\
\hline & 下 俊 & 隆 & 堀 & F & & 潤 & 木 & 下 & & \\
\hline 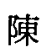 & 琣 & 欽 & 勝 & 亦 & 重 & 弘 & 堀 & 向 & 文 & \\
\hline 篗 & 田良 & 彦 & 杉 & 本 & 伸 & 彦 & 宮 & 岡 & 正 & \\
\hline & 本 英 & 一 & 斉 & 藤 & 利 & 彦 & 芦 & 沢 & 真 & \\
\hline
\end{tabular}

消化管出血の検索のため従来から行われている化学的便潜血反応には，ヒトへモグロビン以外の物質と非 特異的反応をおこすという久点がある。 この問題を解決するため抗七トへモグロビン抗体を作製し，二次元 両者搥散法 (Ouchterlony 法) を用いて兔疫学的便潜血反応を臨床的に倹討した. 非消化管疾患 107 例では $9.3 \%$ ，消化管疾患 150 例をは $48.7 \%$ ，大腸癌60例では $75.0 \%$ に陽性を示し，揵常者30例では全例で除性であ った. Ouchterlony 法は消化管疾患や大腸癌では，化学的便潜血反応であるシオノギスライドB法とほぼ同 様の陽性率を示したが，非消化管疾患おょび健常者で注明らかに低率を示し，偽陽性率の改善が可能であっ た. 従って本法は消化管疾患による出血, 特に大腸澞からの出血のスクリーニング法として有用と考えられ た.

索引用語 : 便潜血反応, 免疫学的便潜血反応, 大腸癌, 大晹癌集団検診, 消化管出血

\section{I. 緒言}

近年本邦においても，食生活の変化に伴い，大腸癌の 発生嚬度は増加の一途をたどっている1。，そのため大腸 集検が積極的に実施され，そのスクリーニング法に大き な関心が集まっている. 大腸X線検查は胃と異なり，そ の前処置や検查法が煩雑であるため，スクリーニング法 としての実施が困難である。また CEA をはじめとし た血清学的検查も，その信頼性に多くの問題がある. そ こで現在便潜血反応を用いた試みが広く行われてい $る^{2-7)}$. しかしこれとて決め手となるスクリーニング法 であるとは言い難い。

従来実施されている化学的便潜血反応に対しては否定 的な意見が根強い(8)が，その最大の諭拠となるのは次の 点である.すなわちその感度を上げれば上げるほど，㒒 陽性が增加してしまうため，実際の集検では感度を低く おさえた反応が用いられている，しかしこのように感度 を下げると，逆に大腸癌からの少量の出血は見逃され， 偽陰性率を増加させる.

そこでわれわれはこの偽陽性（偽陰性）の問題を解決 すべく, 抗ヒトへモグロビン抗体を用いた免疫学的方法
に着目した9)。この方法は特異性に優れているが，使用 する抗血清の特異性，反応方法，感度等に関し問題があ る. そのため臨床的検討も少ない，今回われわれは等電 点電気泳動法にて分離したヒトへモグロビンを用い抗 トヘモグロビン抗体を作製し，この抗血清を用いOuchterlony 法により免疫学的便潜血反応の躁床的検討を行 った.

\section{II. 方 法}

\section{1. 溶血液の調製}

ヘパリン加採血新鮮血を生理食塩水で 4 回洗浄後，血 球量の 2 倍量の蒸留水々 $1 / 2$ 量の四塩化炭素を加え，充 分振蕰した後 $3000 \mathrm{rpm}$ で20分閣遠心し，その上清を溶 血液とした.

2. ヒトへモグロビンの分離，調製

Davies の方法 ${ }^{00}$ に従い，LKB 社製泳動装置を用い， 平板等電点電気泳動法により行ったすなわちアンホラ イン $\mathrm{pH} 7-9, \mathrm{pH}$ 5-7 を加え紫外線により重合させた $25 \mathrm{~cm} \times 10 \mathrm{~cm} \times 0.1 \mathrm{~cm}$ のポリアクリルアミドダル板を作 製し， $5 \mathrm{~mm} \times 3 \mathrm{~mm}$ の濾紙にへモグロビン浱度として $3 \mathrm{~g} / \mathrm{dl}$ に調製した溶血液 $3 \mu \mathrm{l}$ を浸みこませたもの20枚 
を陽極側から $1 \mathrm{~cm}$ の部位にサンプリングし， $500 \mathrm{~V} ， 1$ 時間通電後， $800 \mathrm{~V} ， 6$ 時間通電し，ヒトへモグロビン の分離を行った. 分離後, ゲルをクマシーブリリアント プルーによる蛋白染色 ${ }^{11}$ 及ひひ 0 -ジアニヂンによるへモ グロビン染色 ${ }^{12}$ を行い分離を確認した. 次にへモグロビ ンの最も分離帯の太い部分を切り取り，蒸留水にて抽出 した.

\section{3. 抗ヒトヘモグロビン抗体の作製}

抗血清は家鬼を用い作製した. 前記抽出したヒトへモ グロビンを $1 \mathrm{mg} / \mathrm{ml}$ に調製し，等量の Freund 完全ア ジュバンドと混和し，家鬼の foot pad に $2 \mathrm{ml}$ 注射し た. そしてその 2 週および 3 週後に同様のヒトへモグロ ビン $1 \mathrm{ml}$ を皮下に注射し, 最終免疫の 1 週間後に力価 の上昇を確認した後採血し, 抗血清を分離, 作製した.

\section{4. 免疫学的便潜血反応}

糞便を食事制限なしで小指頭大採取し, $2.0 \mathrm{ml}$ の蒸留 水で混和し， $3000 \mathrm{rpm}$ で 5 分間遠心し，その上清と抗 血清との反応を Ouchterlony 法で検索した.

Ouchterlony 法はリン酸緩衝液（1.0M，pH 7.6）を 含む $1.5 \%$ Agar 寒天板を用いて行ない, 室温, 24 時間 後に沈隆線の有無を判定した.

5. 化学的便潜血反応

シオノギスライド A, B 法を Ouchterlony 法に使用 した同一検体を用いて行った.

\section{III. 対}

1982 年 4 月より 1984 年 4 月までの 2 年間の通院及び入 院患者を対象とした。

非消化管疾患群は107例で, その内訳は肝，胆道疾患 30 例, 血液疾患 20 例, 糖尿病 17 例, 循環器疾患 17 例, 呼吸 器疾患11例，その他12例であった.

消化管疾患群は 150 例で，その内訳は食道癌 9 例， 胃, 十二指腸潰瘍25例，胃癌34例（進行癌25例，早期癌 9 例), 大腸癌（すべて進行癌）60例，その他22例であ った.

健常群は合計 30 例で，X線あるいは内視鏡にて検 索 し，上部，下部消化管ともに異常を認めず，さらに痔核 の無いことが確認されたものである.

\section{IV. 結 果}

\section{1. 等電点電気泳動による溶血液の分離}

等電点電気泳動により，ポリアクリルアミドゲル板は 陽極側から陰極側へ $\mathrm{pH} 5.5$ から $\mathrm{pH} 8.0$ までほぼ直線 の $\mathrm{pH}$ 勾配が得られた (Fig. 1).ささらに溶血液の分離 は明瞭に行なわれ (Fig. 2). 最も収量の多い分離帯を 切り出し，蒸留水で溶出し，これをへモグロビンAとし

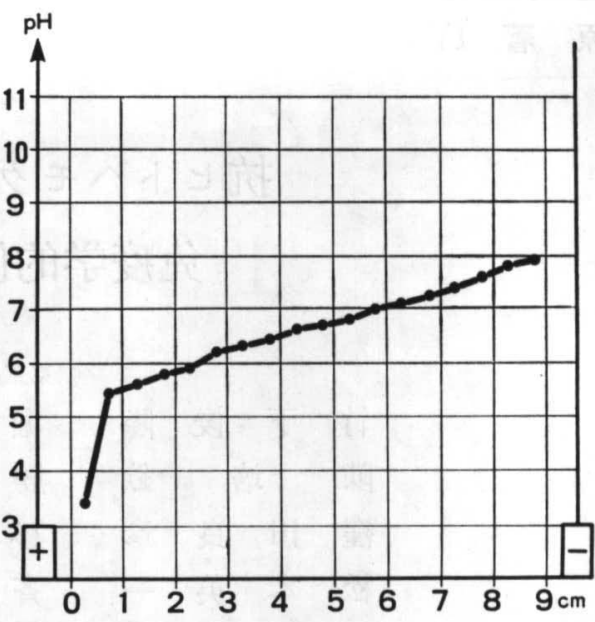

Fig. $1 \mathrm{pH}$ gradient of isoelectric focusing

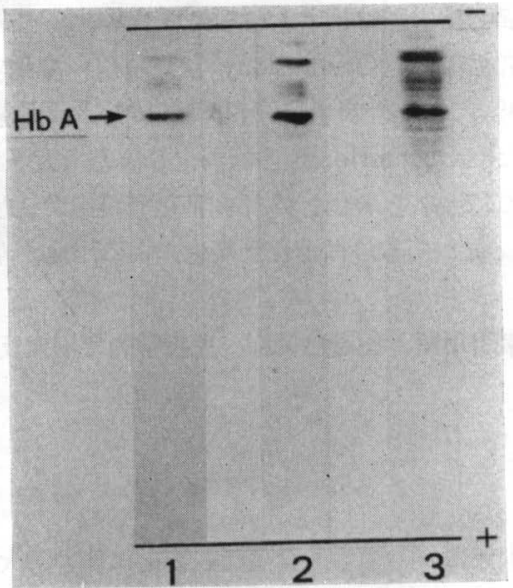

1. non staining

2. staining by Brilliant Cresyl Blue

3 . staining by O-Dianisidine

Fig. 2 Isoelectric focusing of human hemolysate

た.この部の $\mathrm{pH}$ は7.1であった. またこの溶出液をセ ルローアセテート膜電気泳動を行い, へモグロビンAで あることを確認した．未染色拉よびへモグロピン染色で 認められなかった非へモグロビン蛋白が蛋白染色にて $\mathrm{pH}$ 6.8から酸性側に数本認められた (Fig. 2).

2. 抗血清の特異性と感度

抗血清と溶血液との反応を免疫電気泳動法により行 い，特異性を確認した (Fig. 3).

またヒト, ウシ，ウマ，ブタ，ニワトリ，ヒッジ溶血 液との反応を Ouchterlony 法で行ない，ヒト溶血液と のみ反応することを確認した（Fig. 4).

Ouchterlony 法での抗血清のヒトへモグロビン検出最 低濃度は溶血液を蒸留水で希釈した場合 $2 \mathrm{mg} / \mathrm{dl}$ であっ た. 


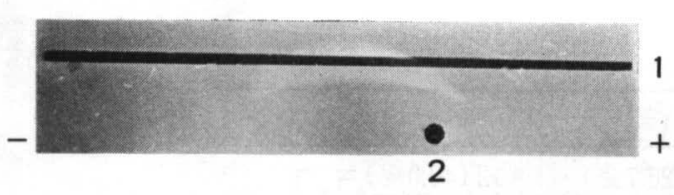

1 : anti human hemoglobin antiserum

2 : human hemolysate

Fig. 3 Immunoelectrophoresis of human hemolysate against anti human hemoglobin antiserum

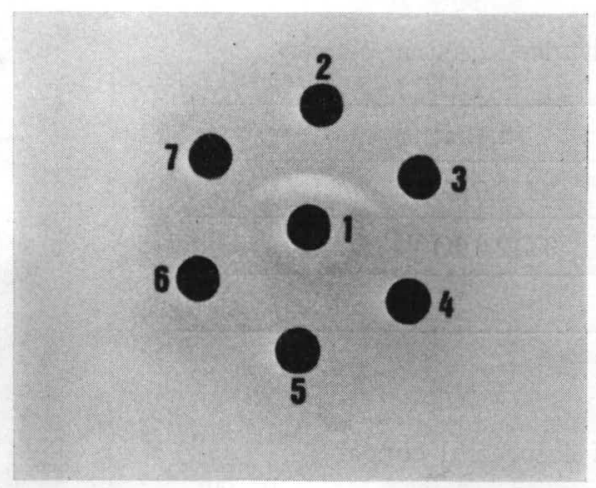

1 : anti human hemoglobin antiserum, 2 : human hemolysate, 3 : bovine hemolysate, 4 : swine hemolysate, 5 : horse hemolysate, 6 : rabbit hemolysate, 7 : sheep hemolysate

Fig. 4 Double immunodiffusion of human and animal hemolysate against anti human hemoglobin antiserum

\section{3. 臨床的検討}

検査対象を非消化管疾患, 消化管疾患, 健常者の三群 に分けた. さらに消化管疾患のなかで出血の可能性が高
いと考えられる胃進行癌と大腸癌について検討した.

\section{1）非消化管疾患}

陰性例を比較すると，スライドA法で23例 (21.5\%), スライドB法で62例 (57.9\%), Ouchterlony 法で97例 (90.7\%) で, Ouchterlony 法での陰性率が他の 2 法に に比し，有意に高率であった（Table 1).

2）消化管疾患

陽性例を比較すると，スライドA法で99例 (66.0\%), スライドB法で78例 $(52.0 \%)$, Ouchterlony 法で73例 (48.7\%) であり, スライドA法に比し Ouchterlony 法 での陽性率は有意に低率であったが，スライド B法と Ouchterlony 法では有意差を認めなかった（Table 2).

\section{3）健常者}

陰性例を比較すると， スライドA法で12例 (40.0\%), スライドB法で19例 (63.3\%), Ouchterlony 法で全例 陰性であり, Ouchterlony 法はスライド A, B 法に対 し有意差を認めた（Table 3).

\section{4) 胃進行癌}

陽性例を比較すると，スライドA法で21例 (84.0\%), スライドB法で 16 例 (64.0\%), Ouchterlony 法 11 例 (44.0\%) であり, スライドA法と Ouchterlony 法で有 意差を認めるも, Ouchterlony 法とスライドB法では有 意差は認められなかった (Table 4).

\section{5）大腸癌}

陽性例を比較すると，スライドA法を48例（80.0\%）， スライドB法で42例 (70.0\%), Ouchterlony 法で45例 (75.0\%) であり，スライドA法で高い陽性率を示した が, 各方法間での有意差は認められなかった (Table 5).

Table 1 Occult blood test of non-digestive disease

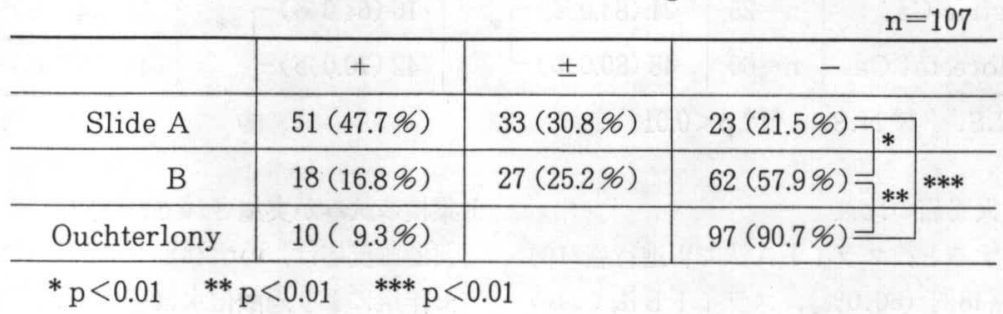

Table 2 Occult blood test of digestive disease

\begin{tabular}{|c|c|c|c|c|c|}
\hline & + & & & \pm & - \\
\hline Slide A & $99(66.0 \%) 7$ & $*$ & & $15(10.0 \%)$ & $36(24.0 \%)$ \\
\hline $\mathrm{B}$ & $78(52.0 \%)$ & $* *$ & $* * *$ & $17(11.3 \%)$ & $55(36.7 \%)$ \\
\hline Ouchterlony & $73(48.7 \%)=$ & 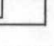 & & & $77(51.3 \%)$ \\
\hline
\end{tabular}

$$
* \mathrm{p}<0.05 \quad * * \text { N.S. } \quad * * * \mathrm{p}<0.01
$$


Table 3 Occult blood test of normal subject

$\left.\begin{array}{c|c|c|c}\hline & + & \pm & - \\ \hline \text { Slide A } & 10(33.3 \%) & 8(26.7 \%) & 12(40.0 \%) \\ \hline \mathrm{B} & 6(20.0 \%) & 5(16.7 \%) & 19(63.3 \%)]_{* *}^{*} * * * \\ \hline \text { Ouchterlony } & 0(0 \%) & & 30(100 \%)\end{array}\right]$

*N.S. $\quad * * \mathrm{p}<0.01 \quad * * * \mathrm{p}<0.01$

Table 4 Occult blood test of advanced gastric cancer

\begin{tabular}{|c|c|c|c|c|}
\hline & + & & \pm & - \\
\hline Slide A & $21(84.0 \%) 7 *$ & & $3(12.0 \%)$ & $1(4.0 \%)$ \\
\hline B & $16(64.0 \%)]_{* *}$ & $* * *$ & $3(12.0 \%)$ & $6(24.0 \%)$ \\
\hline Ouchterlony & $11(44.0 \%)=$ & & & $14(56.0 \%)$ \\
\hline
\end{tabular}

*N.S. ${ }^{* *}$ N.S. $\quad * * * p<0.01$

Table 5 Occult blood test of colorectal cancer

\begin{tabular}{|c|c|c|c|c|}
\hline & + & & \pm & - \\
\hline Slide A & $48(80.0 \%) \overline{7}$ & & $4(6.7 \%)$ & $8(13.3 \%)$ \\
\hline B & $42(70.0 \%)]_{* *}$ & $* * *$ & $7(11.7 \%)$ & $11(18.3 \%)$ \\
\hline Ouchterlony & $45(75.0 \%)$ & & & $15(25.0 \%)$ \\
\hline
\end{tabular}

$*$ N.S. $\quad * *$ N.S. $\quad * *$ N.S.

Table 6 Relationship between occult blood test and occupying site of advanced digestive cancer

\begin{tabular}{|c|c|c|c|c|}
\hline & & Slide $A(+)$ & Slide $B(+)$ & Ouchterlony (+) \\
\hline Gastric Ca. & $\mathrm{n}=25$ & $21(84.0 \%) 7 *$ & $16(64.0 \%) \neg * *$ & $11(44.0 \%)]_{* * *}$ \\
\hline Colorectal Ca. & $\mathrm{n}=60$ & $48(80.0 \%)$ & $42(70.0 \%)$ & $45(75.0 \%)$ \\
\hline
\end{tabular}

${ }^{*}$ N.S. $\quad * *$ N.S. $\quad * * * p<0.01$

6）胃進行癌と大腸癌の比較

陽性例の比較をすると，スライドA洗で胃進行癌21例 $(84.0 \%)$ ，大腸癌 48 例 $(80.0 \%)$ ，スライドB法でおの 打の，16例 $(64.0 \%) ， 42$ 例 (70.0\%), Ouchterlony 法 でおのおの，11例 (44.0\%)，45例 $(75.0 \%)$ であり， スライド $\mathrm{A}, \mathrm{B}$ 法共に胃進行渻と大腸癌の間で有意差 を認めなかったが, Ouchterlony 法では大腸癌で有意に 高以陽性率を示した（Table 6).

\section{V. 考察}

近年本邦においても，大腸癌の増加に伴い便潜血反応 を早期発見の為のスクリーニング法として用いた大腸癌
集検の試みが実施されている4-7)、今まで行われていた 便潜血反応は，いずれもへモグロビンのペルオキシダー ゼ作用により過酸化水素を分解し，その色の変化に上り へモグロビンの有無を検出するものである，呈色物質の 違いにより, オルトトリヂン法, ベンチヂン法, グァヤ ック法などの方法があるが，これらのへモグロビン検出 感度の差は呈色物質の違いによるものである. そして, スライド法などの簡便法も含め, いずれの便潜血反応も ペルオキシダーゼ作用によるもので本質的に同一のもの である.このペルオキシダーゼ作用はヒトへモグロビン に特異的なものではなく, ウシ，ブタなどの動物のへモ グロビンやホウレン草, キャベッなどの食䬣成分，さら 
に注鉄鼡,クロロフィルなどの薬剤にも認められるため， 食事や薬剤の制限なしでは偽陽性と判定される場合が多 く信頼性に欠ける，最も感度の高いオルトトリヂン法で は正常者の $90 \%$ で陽性となり，肉類を禁ずるなどの食事 制限を行ってむ70\%で陽性になるといわれている13)，今 回われわれの結果でもオルトトリヂン法に近似する感度 のスライドA法では非消化管疾患の $47.3 \%$ ，健常者の33 \%に陽性を示し，感度をグァヤック法にまで下げたスラ イドB法でも各タ， $17.3 \% ， 20.0 \%$ で陽性であった。 そ れに比べ，今回の免疫学的方法では非消化管疾患の陽性 率が9.1\%と有意に低く，また健常者30例でも全例陰性 であり，臨床的にも特異性が確認された。

抗ヒトへモグロビン抗体を用いた免疫学的便潜血反応 は1974年の Adams の報告 ${ }^{14)}$ に始まる. 本法と従来の化 学的便潜血反虑との決定的な違いはヒトへモグロビンに のみ反応するという特異性にある.

一般に脊椎動物のへモグロビンは，扝のおの1個のへ 厶を含む 2 本の $\alpha$ 鎖と 2 本の $\beta$ 鎖より構成される。 へム部分はすべての動物に共通であり，動物間の差が認 められるのは蛋白部分の $\alpha$ 鎖および $\beta$ 鎖のアミノ酸配 列である.この差によりへモグロビンの免疫学的種属特 異性が決定されるといわれている。この差はヒトに近緑 なサルにおいて最む小さく，七卜成人の結晶化へモグロ ビン溶液を抗原として用いた 抗血清ではイヌ，ネコ， ウマ，サルとの交差反応を示すここの交差反応のうちサ ルを除いた動物のものは，大部分赤血球中に含まれる catalase, carbonic hydrase などの血球酵素である非へ モグロビン蛋白（NHP）により吸収されてしまう。す なわちこのような粗抗原を用いて作製した抗血清でも，

NHP で吸収すればサル以外の動物は特異性のうえでは 問題にならないと考えられる15)。しかし吸収操作による 抗血清の力伍の低下は避けられず，特異性の高い高力価 の抗血清を得るには NHP を除去したより精製された へモグロビンの免疫が望まれる.

免疫学的便潜血反応の報告のらち，ヒトへモグロビン の分離に関しての具体的記载は少なく, Barrows ら ${ }^{16)}$ Sephadex A-50を用いたカラムクロマトグラフィーによ る Williams ら17の方法の引用にとどまる，その結果 ヒ卜溶血液から NHP を含む4成分の分離ボ可能で, そのうち最大ピークのへモグロビン Ao を抗原として 用いている。

ヒトへモグロビンの分離は古くから種々の方法で行な われているが，近年今回の検查で使用した等電点電気泳 動法（IEEP）による報告が増加している18,19)。 IEEP によれば從来のセルロースア七テート膜電気泳動や DEAE セルロースカラムクロマト法により分離されな

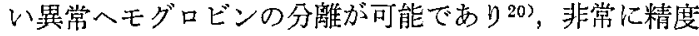
の高いへモグロビンの分離が行なわれている。したがっ てこれを免疫原として用いれば特異性の高い抗血清の作 製が可能と思われる.IEEP によるヒト溶血液の分離は， 未染色で陽極側から $\mathrm{A}, \mathrm{F}, \mathrm{A}_{2}$ の3 種の主要へモグロ ビンを含め $3-7$ 本のへモグロビンを，また蛋白染色後 には15本のへモグロビンと12 13本の NHP の分離が 可能といわれている21). われわれの分離でも未染色で 7 -8本，へモグロビン染色後で12-13本，蛋白染色後で 15一-16本の分離带が認められ，非常に精度の高い分離が 可能であった．また得られたへモグロビンは pI 7.1付 近に認められ諸家の報告と一致している.

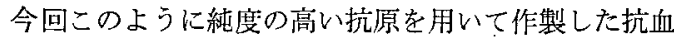
清は Ouchterlony 法㧍よび免疫電気泳動法により， NHPはもちろん七ト以外の動物の溶血液とも反応せず， 高い特異性のものが得られた。 また感度も Ouchterlony 法ではへモグロビン濃度 $2 \mathrm{mg} / \mathrm{dl}$ と良好であった．特異 性に関しては前回のわれわれの報告9 に比べ，今回は偽 陽性が著しく低下していた，今回使用した抗血清の優秀 性が特異性の面で証明されたものと考えられる.

このように免疫学的便潜血反応は特異性に関してほぼ 満足できるものと思われるが，消化管疾患，特に大腸癌 のスクリーニングとして，どの程度の感度を必要とする ものであるらか，大腸癌，ポリープでの従来の便潜血反 応の結果を見ると，その感度を上げればそれだけ陽性率 は上がる. 大腸進行癌では Cameron ら22)のグァヤック 法52\%， ベンチヂン法64\%，多田ら ${ }^{29}$ のオルトトリデン 法で98\%といわれている．もちうんこの中には偽陽性も 含まれてはいるが，最も感度の高いオルトトリヂン法で 陽性率が最も高く，反忘の感度が下がるにつれ陽性率も 下がっている. 一方食事成分や薬剂の影響のない免疫学 的方法では感度を上げれば上げる程，偽陽性を考虑する ことなく，小さな病変からの少量の出血が検出できるも のと考えられる。しかしあまりに感度を上げすぎればロ 腔内や鼻腔などの胃腸病変以外からの微量出血で陽性と なる例が增加し，また健常者でもわずかながら出血の可 能性があるとの報告 ${ }^{24)}$ あり，偽陽性増加の可能性があ ると思われる。

今回われわれが検討した Ouchterlony 法の感度は臨 床的にスライドB法とほぼ等しいものであった。スライ ド $\mathrm{B}$ 法では諸家の報告でも大腸㴦の約 $1 / 4$ で陰性となり 不十分である.しかしスライドB法を平均 2 回施行する ことにより大腸早期澏 $88 \%$ ，大腸腺腫 $77 \%$ ，3 日間連続 して検索すると，大腸進行癌 $100 \%$, 大腸早期癌 $93 \%$, 大腸ポリープ67\%の陽性となり26,27)，偽陽性を考虑して も，Ouchterlony 法で2-3 日間検索すれば同様の結果 
が得られるものと考えられる。したがって免疫学的反応 の感度は Ouchterlony 法よりやや敏感なもので十分で あるとも考元られるが，今後高感度の免疫学的方法での 検討が必要と思われる.

臨床的検討で注，大腸癌でスライドB法と Ouchterlony 法で陽性者の割合はほぼ等しかったが，胃内出血が 強く疑われる胃進行癌の結果では，Ouchterlony 法で大 腸澏に比し陽性率が有意に低く，免疫学的方法に上ると 胃疾患からの出血で偽陰性となる可能性の大きいこと を示している。また in vivoでのわれわれの実験でも胃液 と溶血液を $37^{\circ} \mathrm{C}, 30$ 分閒反応させることにより Ouchterlony 法で反応が㓌性化することが証明されている。つ まり胃液ではへモグロビンのペルオキシダーゼ活性は不 活化されず，抗原性が変性されるものと考えられる.し かしその本態は不明であり今後さらに检討を要する.

免疫学的方法が比較的下部消化管疾患の出血に特異性 が高いことは大腸癌発見のスクリーニングとして，より 有効な方法と考えられる. Burton ら27》は免疫電気泳動 による免疫学的便潜血反忘により，上部消化管疾患の出 血と下部消化管の出血で注, へモグロビンの移動度の違 いにより出血部位の鑑別が可能であり，それは膵液中の carbohydrase の作用によるへモグロビンの変化による 為であると述べている．われわれの成績でも消化液中の 蛋白分解酵素によるへモグロビン抗原決定基の変化によ るものと考兄られる. 今後種々の酵素や酸, アルカリ等 でのへモグロビン処理による変性へモグロビンに対する 種々の抗体を作製することにより，消化管出血の部位決 定に免疫学的便潜血反虑が決定的な検査法となる可能性 考えられる。

以上のごとく, 免疫学的便潜血反忘法非常に優れた方 法と考えられるが, Ouchterlony 法では操作が繁雑であ り，現在より簡便な Latex 凝集反応を用いた方法を検 討して招り28)実用化されるものと確信している.

\section{V. 結 語}

ヒト溶血液より等電点電気泳動法によりヒトへモグロ ビンを分離し，これを家鬼に免疫し，抗ヒトへモグロビ ン抗体を作製した.この抗血清を用い瓷便を材料㳊疫 学的便潜血反応を Ouchterlony 法で行った.

1）等電点電気泳動法によるへモグロビンの分離は非 常に優れていた。

2）作製した抗血清は七ト以外の動物溶血液とは反応 せず，特異性に優れていた。

3）大腸癌での陽性率は $75 \%$ であり，シオノギスライ ドB法70\%とほぼ同じ成績であった。

4）健常者では全例除性であり，シオノギスライド法
に比し偽陽性率が低下した。

5） Ouchterlony 法では上部消化管疾患より下部消化 管疾患からの出血に対する陽性率が高かった。

以上のごとく免疫学的便潜血反念注従来の化学的便潜 血反応の欠点である非特異的反店を呈することが少な く, 消化管疾患からの出血, 特に下部消化管疾患による 出血の検出に有効であると考えられる.

\section{文献}

1）平山 雄：大腸ガンの疫学的変遷と今後の展 望。目本臨床 $39: 2006-2016 ， 1981$

2) Greegor DH : Occult blood testing for detection of asymptmatic colon cancer. Cancer 34: 131-134, 1971

3) Winawer SJ, Sherloch P, Schotlfeld D, et al: Screening for colon cancer. Gastroenterology $70: 783-789,1976$

4）相沢中, 福士道夫, 佐野正明ほか：大腸集団 検診. 消化器集団檢診 $59: 39-44,1983$

5）小林世美, 吉井由利, 松浦昭ほ加: 胃集検に併 用した便潜血テストによる大腸集検. 消化器集 団検診 $60: 7-12,1983$

6）藤田㫤英, 中野陽典,太田潤ほか: 大腸演の 集団検診一とくに便潜血スクリーニングの有用 性の㭘討．消化器集団㛟䧐 $61: 49-57,1983$

7）吉川宣辉，笹井 平，山本秀栈汪か：職域にお ける大晹癌集団検診。大腸肛門誌 $36: 95-100$, 1983

8) National Institutes of Health: Consensus does not recommend mass screening for colorectal cancer; mortality reduction not shown. Am J Med Ass 240:2625-2626, 1978

9）竹下俊隆，杉本伸彦，芦沢真六：便潜血反心に よるスタリーニング。大腸肛門誌 $35: 561-$ 566, 1982

10) Davies $H$ : Thin-layer gel isoelectric focusing, in Arbuthnott, J. P. and Beeley, J. A. ed., London: Butterworths. p97-113

11) Vesterberg $O$ : Isoelectric focusing of proteins in polyacrylamide gels. Biophys Acta $257: 11-19, \quad 1972$

12) Owen JA, Silberman HJ, Got C : Detection of Haemoglobinhaptoglobin complexes and other substances with peroxidase activity after zone electrophoresis. Nature 182:1373, 1958

13) Heinrich HC, Benn H-P : Chemischer oder immunologischer okkultblut-nachweis im stuhl bei der fruhdiagnostik des kolorektalen karzinoms ?. Dtsch Med W wchr $107: 307-$ 310,1982

14) Adams EC, Layman KM: Immunochemical confirmation of gastrointestinal bleeding. Ann Clin Lab Sci $4: 343-349,1974$

15）原 三郎，井上徳治，大島美奈子ほか：七卜 


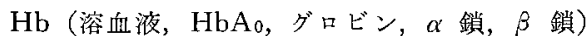
免疫血清に打注反応，副反忘について，日 本法医誌 $36: 335-343 ， 1982$

16) Barrows GH, Burton RM, Jarrett DD, et al : Immunochemical detection of human blood in feces. American Society of Clinical Pathologists $69: 342-346,1978$

17) Williams RC and Tsay K-Y : A convenient chromatographic method for the prepartion of human hemoglobin. Anal Bicochem 54: $137-145,1973$

18) Koepke JA, Thoma JF and Schmidt RM : Identification of human hemoglobins by use of isoelectric focusing in gel. Clin Chem $21: 1953-1955,1975$

19) Basset P, Beuzard Y, Garel MC, et al : Isoelectric focusing of human hemoglobin. BIood $51: 971-982,1978$

20）原野昭雄，原野恵子，小出智子ほか：等電点分 画法による異常血色素の Mass Screening 法. 臨床病理 $28: 149-152,1980$

21) Kramlova M, Pristoupil TI, Ulrych S, et al : Electrofocusing of stroma-free hemolyzates of human erythrocyles. Chromatogr 193:
$515-519, \quad 1980$

22) Cameron AB : Detection of cancer and adenomas of the colon. Am J Surg $101: 23-25$, 1961

23）多田正大：大腸癌検診に関古る臨林的研究. 大 腸肛門誌 $32: 537-545 ， 1979$

24) Anderson ET, Passovoy $M$ and Trobaugh FE : Quantitation of gastrointestinal bleeding by use of a large volume scintillation detector. J Nuc Med $7: 612-619,1966$

25）多田正大，赤坂裕三，川井㤵书：大腸癌早期発 見のための便潜血検查の再評価，大腸肛門誌 $34: 317-320,1981$

26）吉井由利，小林世美，黑田岳雄䚾か：大腸早期 癌及び腺腫：便潜血テストの有用性と出血関連 要因について。大腸肛閒誌 $34: 220-223,1981$

27) Burton RM, Landreth and Barrows GH : Appearance, properties, and origin of altered human hemoglobin in feces. Lab Invest 35 : 111-115, 1976

28）竹下俊隆，木下 剛，陳 培欽ほ加：抗体感作 ラテックス凝集反底を用いた免疫学的便潜血反 応.大腸肛閒誌 $37: 432,1984$

\title{
Immunological Fecal Occult Blood Testing with Anti-human Hemoglobin Antibody
}

\author{
T. Takeshita, J. Horiguchi, T. Kinoshita, P. Chen, \\ S. Katsumata, F. Horimukai, Y. Kubota, N. Sugimoto, \\ M. Miyaoka, E. Matsumoto, T. Saito and S. Ashizawa \\ Department of Internal Medicine, Tokyo Medical College, Tokyo
}

It is well know that traditional chemical fecal occult blood testing for survey of gastrointestinal bleeding had the demerit of non-specific reaction with non-hemoglobin substances. To settle the ploblem, clinical study of immunochemical fecal occult blood testing with Ouchterlony's method was evaluated. The result showed test positive in $9.3 \%$ of 107 nongastrointestinal diseases, $48.7 \%$ of 150 gastrointestinal diseases and $75 \%$ of 60 colorectal neoplastic patients and test negative in all 30 healthy controls. The immunochemical test revealed almostly the same positive rate as chemical Shionogi slide test. Nevertheless, the lower positive rate in non-gastrointestinal tract patients and healthy controls immunologically pointed that elimination false positive caused be realised. Therefore, we think that application of immunological fecal occult blood testing is available for the screening of gastrointetinal hemorrhage especially colorectal neoplasia. 